\title{
Miasto - wyobrażenie - refrakcja. O niemieckości Gdańska w rosyjskim przekładzie Hanemanna Stefana Chwina
}

Przedmiot artykułu stanowi powieść Stefana Chwina Hanemann oraz jej rosyjski przekład autorstwa Kseni Starosielskiej. Konfrontacja tekstów zorientowana jest na zawarty w nich obraz Gdańska jako miasta, w którym silnie zaznaczyła się obecność kultury niemieckiej. Pragnę zająć się mało dotąd zbadanym zagadnieniem reprezentacji trzeciej kultury w przekładzie, równocześnie podejmując problematykę miejsc wyobrażonych i wielojęzyczności.

Dawny, wielokulturowy Gdańsk jest miejscem wyobrażonym już dla (większości) dzisiejszych polskich odbiorców, zaś przesunięcie - poprzez przekład - w inną kulturę pogłębia tę perspektywę. Ponadto pewne elementy językowe i pojęciowe wykorzystane w tkance powieściowej są wprawdzie obecne w bagażu kognitywnym odbiorców prymarnych, lecz czytelnikowi rosyjskiemu mogą wydawać się dużo odleglejsze kulturowo.

Tekst oryginału ${ }^{\mathrm{I}}$ odtwarza realia sprzed kilkudziesięciu lat. Powieściowe wyobrażenie miasta $\mathrm{z}$ tego okresu budowane jest przede wszystkim za pomocą nazw własnych (Danzig, Langfuhr, Lessingstrasse, „Stern”). Poza onomastyką niezbyt liczne są typowe wtręty obcojęzyczne (Mutti, Briefe), stosunkowo często natomiast pojawiają się nawiązania do kultury niemieckiej - malarstwa, literatury, kultury materialnej.

Przy tłumaczeniu z języka polskiego na rosyjski tego typu jednostki stanowią tzw. elementy trzeciej kultury, czyli - w myśl definicji Doroty Urbanek - „te elementy tekstu oryginału i/lub przekładu, które są obce zarówno w języku i kulturze oryginału,

I S. Chwin, Hanemann, Tytuł, Gdańsk [2008]. Wszystkie cytaty z oryginału pochodzą $\mathrm{z}$ tego wydania, numery stron podaję w nawiasach w tekście zasadniczym; jeśli wymaga tego kontekst - poprzedzam je skrótem: pol. Powieść ukazała się po raz pierwszy w $1995 \mathrm{r}$. 
jak i w języku i kulturze przekładu" ${ }^{2}$. Ze względu na kulturową motywację użycia niemczyzny przez Chwina przyjęcie takiego określenia wydaje się stosowniejsze $\mathrm{w}$ porównaniu $\mathrm{z}$ preferowanym przez badaczy zachodnich „trzecim językiem”3. Ponadto w zakres pojęcia third language włączane bywają również zagadnienia przekładu dialektów ${ }^{4}$ czy „sztucznego dialektu”, z którymi jednak w tym przypadku nie będziemy mieć do czynienia.

W Hanemannie elementy kultury niemieckiej służa jako środek stylistyczny: budują koloryt lokalny będący zarazem kolorytem epoki, czyli interesującą nas przestrzeń Gdańska. Zarazem w partiach narracyjnych prowadzonych z perspektywy postaci Niemców oraz w ich wypowiedziach stanowią „naturalną część dyskursu”. Pełnią tym samym dwie z funkcji przypisywanych przez Urbanek elementom trzeciej kultury w tekście literackim 5 .

Autorka rosyjskiego przekładu powieści ${ }^{6}$, Ksenia Starosielska, z zasady zachowuje w transkrypcji wszystkie nazwy własne, podejmuje także wysiłek odtworzenia odniesień kulturowych. Równocześnie niezwykle dba o urodę stylistyczną wypowiedzi w języku docelowym. Dlatego odstępuję od klasyfikowania przypadków pełnej, częściowej czy zerowej ekwiwalencji jednostek trzeciej kultury w przekładzie, gdyż można przyjąć, że mamy do czynienia z pełnym, niemal symetrycznym odwzorowaniem. Będą mnie natomiast interesować przypadki rozwiązań nietypowych oraz działania dodatkowe.

Warto przy tym rozpatrzeć, czy - pomimo respektowania przez tłumaczkę trzeciej kultury - $\mathrm{z}$ operacją przekładu wiąże się znacząca refrakcja obrazu kreowanego przez oryginał. Zastanawiając się nad przesunięciami, jakim wyobrażenie miasta ulega przy przeniesieniu na grunt rosyjski, wezmę pod uwagę

${ }^{2}$ D. Urbanek, Elementy trzeciej kultury w procesie przekładu, w: Przekładjezyy - kultura, red. R. Lewicki, Wydawnictwo UMCS, Lublin 2002, s. 63.

3 Por. D. Bellos, The Awkward Issue of L3, „Yearbook of Comparative and General Literature” 2008, t. 54, s. 114-120.

${ }_{4}$ Por. M.C. Gimbert, The Third Language: A Recurrent Textual Restriction in Audiovisual Translation, „Cadernos de Tradução” 2005, t. 2, nr 16, s. 147-160. Z kolei Alan Duff używa określenia „trzeci język” w znaczeniu niemającym nic wspólnego z wtrętami obcojęzycznymi (zob. idem, Third Language: Recurrent Problems of Translation into English, Pergamon Press, Oxford - New York - Toronto - Sydney - Paris - Frankfurt 1981).

5 D. Urbanek, op.cit., s. 63-64. Trzeci przypadek to sytuacja, gdy „język dzieła oryginalnego jest jedynie pośrednikiem w opisie trzeciej kultury" (ibidem, s. 64).

6 С. Хвин, Ханеман. Роман, thum. К.Я. Старосельская, АСТ-Люкс, Москва 2005. Jeśli nie zaznaczono inaczej, cytaty z rosyjskiego przekładu pochodzą $\mathrm{z}$ tego wydania, numery stron podaję w tekście zasadniczym; jeśli wymaga tego kontekst - poprzedzam je skrótem: ros. 
przede wszystkim aspekty językowe i kulturowe, chociaż nie wykluczam zaobserwowania czynników ideologicznych ani patronackich, które zakładał André Lefevere, wprowadzając pojęcie refrakcji do badań nad przekładem w roku 19827.

Zdaniem Lefevere'a refrakcja wiąże się z systemem ograniczeń narzucanym tekstowi przenoszonemu w inny „ośrodek” językowo-kulturowy (źródło tych ograniczeń stanowią instancje regulacyjne, obowiązująca poetyka, system języka). Przyjrzyjmy się zatem czynnikom hamującym transfer lub recepcję, tym bardziej że - jak pisze Anna Legeżyńska - „wyobraźnia tłumacza aktywizuje się w polu swoistych ograniczeń, jakie stwarza obraz świata imaginowany przez autora oryginału" .

W Hanemannie obraz miasta istotnie jest ,imaginowany”. Wizja Gdańska zaproponowana przez Chwina to nie bezpośredni opis, lecz już pewna refrakcja: interpretacja tamtej rzeczywistości dokonana przez Polaka urodzonego po wojnie, a więc - parafrazując tekst powieści - po śmierci tamtego Miasta. Taki jest też punkt widzenia narratora, próbującego rekonstruować sylwetkę i zachowania tytułowej postaci na tle historii małej ojczyzny.

Ze statusem miejsca wyobrażonego, niedostępnego empirycznie, łączą się ograniczenia percepcyjne odbiorców prymarnych, które autor bierze pod uwagę. Do tekstu powieści dołączony jest Klucz do miejsc, czyli opracowany przez Krystynę Chwin glosariusz zestawiający toponimy i mikrotoponimy niemieckie $\mathrm{z}$ ich polskimi odpowiednikami ${ }^{9}$. Chociaż są to odpowiedniości topograficzne, nie zaś językowe, to zestawienie ułatwia proces semantyzacji tekstu. Poza onomastyką $\mathrm{w}$ powieści Chwina pojawiają się nieliczne wtręty niemieckie, zwykle pojedyncze podstawowe słowa, których zrozumienie nie wymaga zaawansowanej znajomości języka (np. Pfeffer, Cigarren, Gespräch). Na stronie redakcyjnej autor podaje też spis wykorzystanych źródeł, w tym Listy Heinricha von Kleista.

W polskim wydaniu nie ma jednak paratekstów objaśniających. Natomiast Starosielska, uwzględniwszy różnice między

7 Zob. A. Lefevere, Mother Courage's Cucumbers: Text, System and Refraction in a Theory of Literature, „Modern Language Studies” 1982, t. 12, nr 4, s. 3-20. W ujęciu Lefevere'a „refrakcje - adaptowanie dzieł literackich dla potrzeb obcej publiczności, dokonywane z zamysłem wywarcia wpływu na sposób, w jaki będą czytane - istnieją w literaturze od zawsze. Do refrakcji dochodzi w oczywisty sposób w tłumaczeniach" (A. Lefevere, Ogórki Matki Courage, thum. A. Sadza, w: Wspótczesne teorie przekładu. Antologia, red. P. Bukowski, M. Heydel, Znak, Kraków 2009, s. 227).

8 A. Legeżyńska, Przekład jako rzecz wyobraźni, w: Przekład artystyczny a wospótczesne teorie translatologiczne, red. P. Fast, Śląsk, Katowice 1998, s. 33.

9 Klucz do miejsc, oprac. K. Chwin, w: S. Chwin, Hanemann, s. 242-245. 
bagażem kognitywnym odbiorców pierwotnych i sekundarnych, opatrzyła tekst rosyjski przypisami. Jest ich pięćdziesiąt cztery, z czego - co ważne - zaledwie połowa dotyczy niemczyzny i kultury niemieckiej.

Przyjrzyjmy się bliżej przekładowi różnych elementów tekstu związanych z trzecim językiem i kulturą. Zacznijmy od nazw własnych, które pod względem frekwencyjnym stanowią główny nośnik kolorytu lokalnego.

Tłumaczka zdecydowała się zachować tytuł w brzmieniu - jak to sama ujmuje - „powściągliwym, oschłym” " czytelnik rosyjski od pierwszej chwili styka się z nośnikiem obcości, początkowo trudnym do zsemantyzowania, bo pozbawionym kontekstu. Wszystkie niemieckie antroponimy i toponimy $\mathrm{w}$ powieści zostały przetranskrybowane $\mathrm{z}$ uwzględnieniem zasad transkrypcji między językiem niemieckim a rosyjskim ${ }^{\text {II }}$, ewentualnie zwyczajowych odpowiedników lub adaptacji fleksyjnej: Langfuhr $\rightarrow$ Лангфур; Walmann $\rightarrow$ Вальман; Heinrich von Kleist $\rightarrow$ Генрих фон Клейст; Liselotte $\rightarrow$ Лизелотта. Rodzi się jednak pytanie o możliwości i stopień semantyzacji tego nazewnictwa w odbiorze czytelniczym.

Zasadniczy przedmiot narracji powieści ujawnia się, choć nie w sposób deklaratywny, w trzecim rozdziale - jest nim „przeszłość umarłego miasta" (s. 28), przy czym tak samo dzieje się w przekładzie: „прошлое умершего города” (s. 31). O jakie jednak miasto chodzi (nazwa pada w tekście nieprędko, i najpierw tylko w tytułach lokalnej prasy: „Danziger Volksstimme”, „Danziger Vorposten” - pol., s. 25-26) ${ }^{\mathrm{I} 2}$ ? Przystępując do lektury bez powziętych z góry założeń i bez znajomości recenzji lub innych utworów Chwina, czytelnik polski będzie kierował się w swojej dedukcji onimami. Tytuł oraz obecne na pierwszych trzech stronach tekstu (s. 5-7) nazwiska: Stein, Kohl, Rotke,

то „Название - сухое, сдержанное, всего лишь фамилия, вдобавок немецкая, - тоже” (К. Старосельская, От переводчика, w: С. Хвин, Ханеман. Роман, tłum. К.Я. Старосельской, «Иностранная литература» 1997, nr 12, s. 25). Dla porównania, tytuł przekładu angielskiego jest bardziej przejrzysty semantycznie i intryguje aliteracją: S. Chwin, Death in Danzig (tłum. P. Boehm, Harcourt, Orlando 2004).

${ }^{\text {I }}$ Por. Д.И. Ермолович, Имена собственные на стыке языков и культур, Валент, Москва 2001, w szczególności s. 156-158. Przykładem adaptacji zwyczajowej jest pojedyncza końcowa spółgłoska w transkrypcji cząstki - mann, jak w nazwisku tytułowego bohatera.

I2 Wprawdzie nazwa Danzig pojawia się w końcowej partii drugiego rozdziału, lecz w szeregu innych nazw, tak że nic nie wskazuje na jej szczególny status: „Opowiadał jej zawsze o tym, co się zdarzyło ważnego i ciekawego w Danzig, Dirschau, Zoppot, a nawet w Marienwerder, więc teraz też chciał jej opowiedzieć...” (s. 20). 
Retz; toponimy Dehlbrück-Allee, Glettkau; aluzja kulturowa: „idee Bleulera” - wskazują na jakieś miasto niemieckie. Jednak obecne wśród nich nazwy Długie Pobrzeże i Wyspa Spichrzów pozwolą znacznej grupie odbiorców prymarnych zidentyfikować miejsce akcji jako Gdańsk, zaś przewaga nazewnictwa germańskiego wskaże na jej czas. W takim kontekście również nazwy typu Elbing czy Thorn (s. 8) mogą zaktualizować się jako Elbląg i Toruń. Trudno oczekiwać, by analogiczny proces kognitywny uruchomiły u czytelnika rosyjskiego nazwy Долгое побережье і Лабазный остров $($ s. 7,9$)$. Starosielska uznała, że nawet pojawiające się na kolejnej stronie „molo w Zoppot” (s. 9), które Polakom niemal na pewno skojarzy się z Trójmiastem, nie naprowadzi czytelnika rosyjskiego na właściwy trop. Dlatego jeszcze w pierwszym rozdziale tłumaczka dołącza przypis: „Главный город - район Гданьска (Данцига)" (s. 14). Główne Miasto, które nie odgrywa w utworze większej roli, jest tu w zasadzie pretekstem do wyeksplikowania miejsca akcji, o czym świadczy i sam przypis, niewnoszący żadnych informacji o położeniu, historii, ani też o znaczeniu danej dzielnicy.

Dodajmy, że miejsce akcji wyraźnie wskazują także parateksty przekładu. Pierwodruk na łamach czasopisma „Иностранная литература" poprzedzała rekomendacja Stanisława Lema ${ }^{\mathrm{I} 3}$ oraz cytowane już słowo od tłumaczki; oboje komentowali fakt osadzenia akcji w Gdańsku. Natomiast w wydaniu książkowym informuje o tym аннотация - nota wydawnicza umieszczana na stronie redakcyjnej większości rosyjskich publikacji ${ }^{14}$.

$\mathrm{Z}$ kolei Klucz do miejsc pozwala czytelnikowi polskiemu choćby nałożyć trasy, które przemierzają bohaterowie, na współczesną siatkę topograficzną. Dla odbiorcy obcego lektura będzie miała charakter raczej semiotyczny niż mimetyczny ${ }^{15}$. Mimo to Starosielska zachowała glosariusz, czy raczej zaadaptowała go dla wydania rosyjskiego ${ }^{16}$. Stanowi on istotnie pomoc w odbiorze, w Hanemannie bowiem ważna jest nie tylko obecność niemieckich toponimów oraz mikrotoponimów, ale również

гз С. Лем, Проза плотного плетения, «Иностранная литература» 1997, nr 12, s. 24-15.

I4 Dla porównania - tekst na czwartej stronie okładki wydania polskiego nie podsuwa najmniejszej wskazówki w tym zakresie. Co ciekawe, nota rosyjska zawiera dodatkową, interpretującą, aluzję do kultury germańskiej - mowa w niej o świecie przeżywającym „Zmierzch bogów”: „Перед вами - Гданьск. До - и после Второй мировой. Мир, переживающий «Сумерки богов»”.

${ }_{5}$ Por. L. Neuger, Wystawianie Szymborskiej. Na marginesie przekładów na jezzyk szwedzki Andersa Bodegårda, ,Teksty Drugie” 1991, nr 4, s. 101-103.

г6 Ключ к местам, oprac. К. Хвин, w: С. Хвин, Ханеман, Москва 2005, s. $282-285$. 
ich dystrybucja w tekście. Dominują one w początkowych partiach książki, lecz gdy narracja przenosi się w okres po 1945 r., wyparte zostają przez onimy polskie. Zatem począwszy od rozdziału Grottgera 17, pojawiają się: Gdańsk - nie Danzig, Tczew nie Dirschau, Wrzeszcz - nie Langfuhr, ulica Grottgera - nie Lessingstrasse itd. Przy dawnym, niemieckim nazewnictwie pozostaje Hanemann. Jednak w rosyjskiej transkrypcji także polskie nazwy często brzmią egzotycznie: „Дубовая, Траугута, Тувима, Морская... [...] Дельбрюкаллее больше не называлась Дельбрюкаллее. В Академию теперь ходили по улице КюриСклодовской” (s. 102). Zapamiętanie tożsamości dwóch obcych elementów (np. Диршау - Тчев) może sprawiać czytelnikom sekundarnym trudność, dlatego zestawienie służy jako praktyczna ściągawka w trakcie lektury. Zachowanie Klucza do miejsc w wariancie przekładowym sprzyja też podkreśleniu dialektyki polskości i niemieckości - jednego $\mathrm{z}$ ważnych aspektów powieści.

Przejdźmy do wtrętów obcojęzycznych. Przeniesienie elementów niemczyzny do tekstu przekładu utrudnia fakt, że język rosyjski posługuje się odmiennym alfabetem. Na przykład w oryginale kilkanaście razy przywoływany jest „gasthaus” przy przystani w Glettkau. Chwin najprawdopodobniej zakładał semantyczną transparentność tego słowa, natomiast Starosielska nie zdecydowała się na pozostawienie wtrętu w formie wyjściowej transkrybuje go (zacmxayc) i opatruje przypisem (s. 6). W tekście rosyjskim transfer (rozumiany jako zachowanie graficznej formy zapisu niemieckiego) objął zaledwie około czterdziestu wyrazów na przestrzeni całej powieści, przy czym z wyjątkiem jednego przypadku wszystkie frazy zostały opatrzone przypisami objaśniającymi znaczenie. Jeśli chodzi o dobór jednostek, które zostały przeniesione, a nie przetranskrybowane, są to przede wszystkim słowa i zwroty pojawiające się w powieści na prawach napisów, jak te na szyldach:

$[. .$.$] złotawe litery { }^{17}$ „Cigarren”, wymalowane na wąskiej fasadzie $[\ldots]$ (s. 26)

[...] золотистые буквы «Cigarren», нарисованные на узком фасаде $[\ldots]$ (s. 28);

${ }^{17} \mathrm{~W}$ całym artykule wyróżnienia w cytatach - M.K. Dla przejrzystości w niektórych cytatach proponuję dwa rodzaje wyróżnień. Cigarren - dawna pisownia, notowana w słowniku Grimmów (1860) oraz, jako przestarzała, w Das große Wörterbuch der deutschen Sprache in 10 Bänden, Dudenverlag, Mannheim 1999. 
[...] na wystawowej szybie kawiarni przy Breitgasse 13 złoty napis „Caffe” [...] (s. 32)

[...] на витрине кафе в доме 13 по Брайтгассе золотую надпись «Caffe» ${ }^{\mathrm{I} 8}[\ldots]$ (s. 36);

[...] na furkoczącym brezencie wielkie napisy „Drogen”, „Chemikalien”, reklamy mebli Wernitza z Brombergu [...] (s. 66)

[... ] на вздувающемся брезенте огромные надписи «Drogen», «Chemikalien», реклама мебели Верница из Бромберга [...] (s. 76).

W oryginalnym brzmieniu pojawiają się tytuły książek gdańszczanina Hermanna Rauschinga:

Пробился бы в руководство партии, никогда б не написал своей «Die Revolution des Nihilismus». И уж тем более «Gespräche mit Hitler»! (s. 30).

Ponadto pozostawiono $\mathrm{w}$ transliteracji przedwojenną oficjalną nazwę miasta (Freie Stadt Danzig, s. 35; Freie Stadt, s. 151), oraz - w sposób chyba dowolny - dwie nazwy związane z polityczną historią Gdańska - Zentrumpartei (s. 27)i Victoria-Schule (s. 150).

W tekście rosyjskim napisy niemieckie gęstnieją, kiedy do miasta wkraczają nowi mieszkańcy - Polacy ze zniszczonej Warszawy i repatrianci ze Wschodu. Chociaż podkreśla się, że miejscowości, dzielnice, ulice noszą nowe miana, to w przekładzie na przestrzeni dwudziestu stron (s. 84-103) występuje największe zagęszczenie transferu. Takie spojrzenie oczami przybyszów wydaje się realizacją pewnej sugestii zawartej w oryginale: wkraczających do Gdańska rodziców narratora przystanek tramwajowy „straszył emaliowaną tabliczką z gotyckim napisem” (s. 70-71). U Starosielskiej: ,деревянная будка трамвайной остановки пугала эмалированной табличкой с готической надписью" (s. 80). Przypadki transferu obserwujemy w następujących kontekstach. Przybysze stykają się z oznaczeniami na sprzętach w poniemieckich domach:

I8 $\mathrm{W}$ tym przypadku - bez przypisu, ale dzięki zachowaniu oryginalnej struktury wypowiedzi - ekwiwalent rodzimy, кaфe, znajduje się w bezpośrednim kontekście. 
Kran był duży, z szerokim, płaskim ujściem, na motylkowatych pokrętłach, pod literkami „Kalt” i „Warm”, nikiel odprysnął w paru miejscach. (s. 83)

И кран был большой, с широким плоским отверстием, никелировка на крыловидных ручках под надписями «Kalt» и «Warm» в нескольких местах облупилась. (s. 95-96)

Na półce, wśród kieliszków z kobaltowego szkła i małych dzbanków z napisem „Pfeffer”, „Salz”, „Zucker”, bielił się owal wazy na zupę $[\ldots] .($ s. 84)

На полке, среди среди рюмок из кобальтового стекла и баночек с надписями «Pfeffer», «Salz», «Zucker» белел овал супницы $[\ldots] .($ s. 96)

Przechowują porzucone przez Niemców pamiątki i fotografie:

Ojciec wstał, ostrożnie zdjął zdjęcie z gwoździa, zdmuchnął pajęczynę z jaśniejszego prostokąta, który został na herbacianej tapecie, obejrzał odwrotną stronę z nadrukiem „Ballerstaedt. Photograph. Atelier” (przy nadruku był atramentowy dopisek „Juli 1938”) [...]. (s. 86)

Отец встал, осторожно снял фотографию с гвоздя, смахнул паутину со светлого прямоугольника, оставшегося на обоях цвета чайной розы, посмотрел на оборотную сторону с печатной надписью «Ballerstaedt. Photograph. Atelier» (под которой чернилами было приписано: «Juli 1938») [...]. (s. 100)

Użytkują pozostawione przez nich materiały piśmienne (tu tekst pieczęci):

Pierwsze formularze, na których Ojciec wypisywał rachunki, zielone, z fioletowymi rubrykami, miały nadruk „Herbert Borkowski. Drogen u. Chemikalien-Grosshandlung. Danzig. Brabank 4”. (s. 88)

Первые бланки, на которых Отец выписывал счета, - зеленые, разграфленные фиолетовыми линиями, - были снабжены штампом «Herbert Borkowski. Drogen u. Chemikalien-Grosshandlung. Danzig. Brabank, 4». (s. 102) 
Obcują z nielicznymi pozostałymi w Gdańsku Niemcami:

Bo dużo pielęgniarek w Akademii to były Niemki. Takie pod trzydziestkę. Krankenhaus Schwester. Wszystkie nosiły się tak samo [...]. (s. 89)

[...] среди сестер в Академии было много немок. Таких, лет под тридцать. Krankenhausschwester. Одевались все они одинаково [...]. (s. 103)

Polacy stopniowo oswajają i przejmują przestrzeń miasta, także w sensie językowym. Niemieckie toponimy (w rosyjskiej transkrypcji) pojawiają się tylko w wypowiedziach lub partiach narracji prowadzonych z punktu widzenia niemieckich bohaterów (Hanemann, list Martina Retza, ros., s. 116-122), lub Polaków pamiętających czasy Wolnego Miasta i niemieckiej okupacji w Gdańsku, jak „pan J.” (w jego wypowiedziach pojawiają się Victoria-Schule i Freie Stadt, ros., s. 150-151). Transliteracja dotyczy jedynie komentarza o charakterze jawnie metajęzykowym, gdzie słowiańskiemu staccato krótkich słów przeciwstawia się germańskie złożenia: „ «Einfuhrungsfeierlichkeit», «Elementarrunterricht» или «Haushaltungsvorstand»" (s. 136). $\mathrm{W}$ oryginale nie są one zsemantyzowane, i zapewne dlatego Starosielska nie wyjaśnia ich znaczenia, nie poprawia również autorskich błędów w transliteracji ${ }^{19}$.

W końcowych partiach utworu powracają już tylko te wtręty, wobec których transliterację zastosowano wcześniej: Zucker, Salz, Pfeffer (s. 182), Briefe(s. 270, 280). Dzięki temu odczuwalne jest zniknięcie niemczyzny z kulturowego pejzażu Gdańska, a zarazem dalsza obecność wprowadzonej i „oswojonej” wcześniej leksyki świadczy o konsekwencji.

Choć tak nieliczne, wtręty odpowiednio eksponują kulturę niemiecką - tłumaczka nie zastosowała bowiem transferu ani w stosunku do nazw własnych, ani do innych wyrazów polskich, nawet kiedy pojawiają się w analogicznych kontekstach, jako napisy. Porównajmy:

I9 W pierwszych dwóch wydaniach oryginału (Marabut, Gdańsk 1995 i 1996), z których mogła korzystać Starosielska, pierwsze dwa z tych wyrazów są zapisane błędnie. W późniejszych edycjach polskich - poprawnie: „Einführungsfeierlichkeit”, „Elementarunterricht” (s. 118, wyd. z 2008). Co ciekawe, w pierwodruku przekładu błędny jest tylko zapis drugiego rzeczownika (zob. «Иностранная литература» 1997, nr 12, s. 71), natomiast w cytowanym wydaniu książkowym - oba. 
wagony z tabliczką „Gdańsk - Koszalin - Szczecin” (s. 110)

вагоны с табличкой «Гданьск - Кошалин - Щецин» (s. 128).

Tłumaczka wzmacnia też wspomnianą funkcję elementów trzeciego języka jako „naturalnej części dyskursu” ${ }^{\circ}$ : o ile u Chwina pojawia się tylko jeden adresatyw niemiecki, Mutti, to przekład wykorzystuje ponadto zwroty grzecznościowe: Frau i Herr. Dzieje się tak jednak wyłącznie w cytowaniach wypowie$\mathrm{dzi}$, nie w partiach narracyjnych. Porównajmy:

«Герр Ханеман, что вы делаете, бога ради, поторопитесь!» - кричала госпожа Вальман с помоста. (s. 59)

Panie Hanemann, szybciej! - wołała pani Walmann. - Na Boga, szybciej! (s. 52)

W liście Retza przytoczenia dialogów zawierają te same wtręty translatorskie: фрау Вирт, герр Реи, фрау Эльза (s. 117-118) wobec zwrotów: „pani Wirth”, „panie Retz”, „pani Elsa” w polskim tekście.

Dodajmy, że Chwin zręcznie posługuje się również germanizmami włączonymi w system języka polskiego. Przykładem może być rzeczownik „cwikier” (s. 8), co Starosielska z konieczności tłumaczy jako пенсне (s. 8), ponieważ język rosyjski dysponuje tu jedynie zapożyczeniem francuskim (słownik rosyjsko-niemiecki podaje odpowiedniość пенсне - Zwicker ${ }^{21}$ ). Starosielska kompensuje tego typu straty, wprowadzając na miejsce neutralnych wyrazów polskich rosyjskie słowa o wyczuwalnym rodowodzie germańskim, na przykład magazyn portowy określa mianem пакгауз (s. 53-62, 118), nie zaś склад.

Odmienność alfabetów staje się przyczyną jeszcze jednego problemu translatorskiego. Pismo gotyckie stanowi w powieści specyficzny emblemat czy metonimię kultury niemieckiej. Ponieważ gotyk to krój pisma łacińskiego, nie ma w języku rosyjskim nazw na poszczególne jego odmiany, tymczasem Chwin wykorzystuje ich wielość jako trop stylistyczny:

[...] oczy szesnastoletniego chłopca z ulicy Bohaterów Westerplatte, powolutku sunące przez pola szwabachy, kolczaste łany fraktury, ciasno splecione łańcuchy gotyku $[. .$.$] . (s. 116)$

${ }^{20}$ Por. D. Urbanek, op.cit., s. 63.

${ }^{2 \pm}$ Zob. М.Я. Цвиллинг, Русско-немеикий словарь / Russisch-Deutsches Wörterbuch, Русский язык Медиа, Москва 2005. 
[...] глазам шестнадцатилетнего подростка с улицы Героев Вестерплатте, потихоньку бредущим по полям готического шрифта, пробирающимся сквозь колючие заросли фрактуры, между тугими цепочками причудливых букв [...]. (s. 134)

W przekładzie pierwszej metafory szwabacha staje się „pismem gotyckim", zatem gotyk w ostatniej partii zdania zostaje zastąpiony peryfrazą „fantastyczne litery”. Są to refleksje jednej z postaci, których relacje składają się na opowieść o Hanemannie. Jego uczeń w czasach powojennych, Andrzej Ch., po latach wspomina swoje problemy z czytaniem szwabachy:

Gotyckie M, splecione z czarnych wstążek, wciąż myliło mi się z W i podwójnym S, abrewiaturą dziwną i podstępną, uparcie podobną do czcionki F, choć przecież wszystko mogłem sobie przećwiczyć już dużo wcześniej w pokoju ojca, gdzie obok Biblii drukowanej cyrylicą stał na półce protestancki modlitewnik z Powiśla, drukowany po polsku, ale gotykiem. (s. 115-116)

Готическую М, сплетенную из черных тесемочек, я вечно путал то $\mathbf{c} \mathbf{W}$, то с удвоенной $\mathbf{S}$, странной и коварной аббревиатурой, упорно прикидывающейся буквой $\mathbf{F}$, хотя мог усвоить все это гораздо раньше, в отцовской комнате, где на полке рядом с Библией на кириллице стоял протестантский молитвенник из Повислья, напечатанный по-польски, но готическим шрифтом. (s. 133)

W tekście rosyjskim powyższego fragmentu obserwujemy zastosowanie łacińskiej czcionki, uzasadnione metatekstowym charakterem opisu, który koncentruje się na kształtach liter, nie na semantyce słów. Warto odnotować ten zabieg w konfrontacji z często powracającym $\mathrm{w}$ powieści monogramem rodziny Walmannów, który ze względu na powiązanie $\mathrm{z}$ nazwiskiem przywoływany jest w przekładzie za pomocą znaku cyrylickiego, np. „монограмма Вальманов - большая затейливая буква В” (s. 46).

Przede wszystkim jednak z powyższego cytatu można wywieść zabieg graficzny zastosowany w pewnym miejscu książkowego wydania przekładu. Otóż w tytule zeznania Stimminga, właściciela gospody, nie opodal której popełnili samobójstwo Heinrich von Kleist i Henrietta Vogel, tekst rosyjski złożono czcionką gotycką (s. 145): 
История, к которой он возвращался, была незамысловатой. Человек, ее рассказавший, повторил только то, что видел и слышал. Название в верхней части страни-

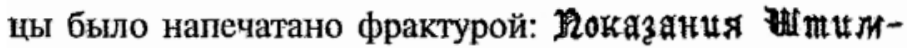

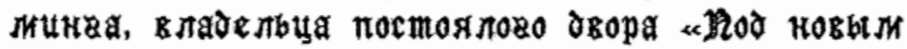

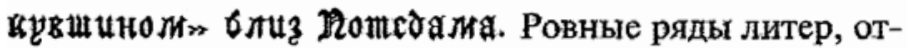
тиснутых на кобленцской бумаге, складывались в плотные колонки готического шрифта. Ханеман приподни-

W paralelnym miejscu tekstu polskiego oraz w czasopiśmiennym pierwodruku przekładu zastosowano jedynie kursywę:

Tytuł umieszczony na górze strony złożono frakturą: Zeznanie Stimminga, wtaściciela zajazdu „Pod nowym dzbanem” nie opodal Poczdamu. (s. 125)

Название в верхней части страницы было напечатано фрактурой: Показания Штимминга, владельца постоялого двора «Под новым кувшином» близ Потсдама ${ }^{22}$.

Zatem cytowana wyżej wzmianka o książce drukowanej po polsku, ale gotykiem, zyskała "praktyczną" realizację w tytule niemieckiego dokumentu, przetłumaczonym za pośrednictwem języka polskiego na rosyjski, lecz złożonym gotykiem... Ten zabieg zapoznaje czytelnika $\mathrm{z}$ niemieckim krojem pisma metoda poglądową, a chwyt został przygotowany przez liczne wzmianki o gotyku oraz obrazowanie nawiązujące do tej formy pisma i do jego lektury.

Jeśli chodzi o odtworzenie realiów i aluzji kulturowych, to jest ono bardzo dokładne. Podobnie jak w oryginale, Danzig w ujęciu Starosielskiej jest miastem, gdzie wystawia się Lobengrina (pol., s. 34 / ros., s. 38), dzieciom czyta baśnie Grimmów (s. 63, 124 / s. 72, 144), pojęcie o geografii czerpie $\mathrm{z}$ atlasu świata Westermanna (s. 86 / s. 100), jada na porcelanie z bawarskiej fabryki Philippa Rosenthala (s. 84 / s. 96). Po ulicach jeżdżą daimler-benze (s. 11 / s. 13) i merzbachy (s. 46 / s. 52), uczesania wzoruje się na Ruth Weyher widzianej w Tajemnicach duszy $\operatorname{Pabsta}^{23}$ (s. 95 / s. 110),

22 „Иностранная литература” 1997, nr 12, s. 145.

23 „[...] причесанную как Рут Вайер в «Тайниках души» Пабста”. Chodzi o Geheimnisse einer Seele, film niemy z 1926 r. (reż. G.W. Pabst, wyst. W. Krauss, R. Weyher, L. Damita). Dodajmy, że Weyher wychowała się w Gdańsku, ale w tym wypadku zarówno rosyjski, jak i polski czytelnik Chwina muszą sięgnąć do zewnętrznych źródeł, by zauważyć tę - zapewne nieprzypadkową dla narra- 
a miłośnicy awangardy wieszają w domach obrazy Noldego i rysunki Kokoschki (s. 26 / s. 29).

W tym kontekście interesujące staje się przede wszystkim pytanie, które $\mathrm{z}$ elementów kulturowych zdaniem tłumaczki wymagały objaśnienia. Przytoczone powyżej albo są znane (jak opera Wagnera), albo też ich znaczenie podpowiada kontekst żadnego $\mathrm{z}$ wymienionych elementów nie opatrzono paratekstem. Natomiast króciutkie przypisy lokują w odpowiednich epokach malarzy (Friedricha, Rungego i Grünewalda), zaś frakturę wyjaśniają jako typ pisma gotyckiego. By pomóc odbiorcom odczytać wartościowanie etyczne wpisane w narrację, tłumaczka wyjaśnia, która gdańska gazeta z lat 30. była pro-, a która antyhitlerowska, czym była organizacja Todta ${ }^{24}$, a także Victoria-Schule (szkoła zamieniona na katownię gestapo). Autorka przekładu wyraźnie nie chce przeciążać tekstu objaśnieniami: bez przypisu pozostawia „śmieszną piosenkę o Heidelore” (pol., s. 103 / ros., s. 119) na tej samej stronie za istotniejszą uznaje wzmiankę o statkach „Gustloff” i „Steuben”, których los - i los ich pasażerów - wpisuje się w ważny dla powieści Chwina motyw zatonięcia ${ }^{25}$. Z kolei w przypisie do rozdziału Listek dębu, gdzie skontrastowane zostają samobójstwa Witkacego i Kleista, zwraca uwagę na rolę wieńców $\mathrm{z}$ liści dębowych w kulturze niemieckiej ${ }^{26}$.

Objaśnianie i interpretowanie niektórych, wybranych, elementów trzeciej kultury tworzy swego rodzaju refrakcję. Jednak strategię Starosielskiej w zakresie paratekstu należy uznać za wyważoną i udaną. Komentarze nie są nadmiernie rozbudowane, ale dostarczają niezbędnego minimum informacji w kontekstach bardziej skomplikowanych z punktu widzenia czytelnika docelowego. Jednocześnie ograniczenie liczby przypisów pozostawia czytelnikom możliwość czerpania satysfakcji z rozszyfrowywania znacznej części aluzji kulturowych i rozpoznawania realiów.

Przejdźmy do kolejnego zagadnienia: reprezentacji w oryginale i przekładzie współistnienia w Gdańsku dwóch religii. W dawnym Danzig obecne było wyznanie protestanckie, jed-

cji - okoliczność. Rosyjski ma zadanie o tyle utrudnione, że Starosielska posłużyła się sformułowaniem innym - mniej dosłownym, bardziej idiomatycznym - niż przyjęty w obiegu rosyjskim tytuł filmu Pabsta (Тайны одной души).

${ }_{24}$ Ale już nie - grupy Volkssturmu; kontekst wskazuje na formację wojskową: „группы Фольксштурма отступили” (s. 41).

25 Przypis przenosi informacje z Klucza do miejsc, co - trzeba przyznać stanowi logiczne rozwiązanie.

26 „В немецкой культуре большую роль играют венки из дубовых листьев, которыми увенчивают героев, поэтов и т.д.” (s. 157). Por. W. Kopaliński, Dąb [hasło], w: idem, Stownik symboli, Wiedza Powszechna, Warszawa 1991, s. 64: „nm. Eichenlaub, w XVIII w. w Niemczech symbol bohaterstwa”. 
nak Chwin ukazuje to niemal wyłącznie przez znamienny brak. Wzmianki pojawiają się w powojennej partii opowieści, kiedy zborów już nie ma, ewentualnie zostały zamienione na katolickie kościoły czy salki parafialne, gdy cmentarze ewangelickie niszczeją bądź są celowo niszczone. Starosielska odtwarza obrazy kirch, wzorem oryginału podkreśla skromność, surowość ich wnętrz. W równym stopniu kontrastują one $\mathrm{z}$ wystrojem kościołów katolickich - o czym pisze Chwin - i z przepychem świątyń prawosławnych, znanym odbiorcy sekundarnemu:

W zborach było inaczej. Prosty krzyż. Białe ściany. Ale teraz w Danzig zborów już nie było. $Z$ tego wielkiego, przy koszarach na Hohenfriedberger Weg zrobiono kino, tak samo $\mathrm{z}$ tego mniejszego przy Jäschkentaler Weg. (s. 168)

Иное дело протестантские храмы. Простой крест. Белые стены. Но сейчас в Данциге кирок уже не осталось. В самой большой, возле казарм на Хёенфридбергервег ${ }^{27}$, устроили кинотеатр, как и в той, что поменьше, на Ешкенталервег. (s. 196)

Dom parafialny kościoła Cystersów, niegdyś ewangelicki dom modlitwy... Żadnych tam barokowych złoceń, gipsowych obłoków, promieni, palm, rokokowych wstążek, puttów, całego tego cudowno-buduarowego wystroju, w którym co niedzielę przed głównym ołtarzem Katedry gotowaliśmy się na spotkanie z Panem. (s. 219)

Приходский дом при костеле цист ерцианцев, некогда евангелический молитвенный дом... Никакой тебе барочной позолоты, гипсовых облаков, лучей, пальм, лент в стиле рококо, ангелочков - ничего похожего на весь этот чудесно-будуарный декор [...]. (s. 254)

Opozycja protestantyzm - katolicyzm stanowi przedłużenie dialektyki polskości i niemieckości w Gdańsku. Dlatego jest rzeczą nie bez znaczenia, że zanika różnica między „kazaniami pastora Knabbe” (s. 169) a „papistowskimi homiliami” (s. 219) księdza Romana - do przekładu obu leksemów użyto rzeczownika проповедь (s. 196, 254). Język docelowy pozostawia tu wprawdzie niewielki wybór, ale można byłoby także posłużyć się słowem поучение. Co więcej, thumaczka ingeruje w obraz tradycji muzycznych Gdańska: dwukrotną wzmiankę o kościelnych ka-

${ }_{27}$ Transkrypcja odzwierciedla zapis „Hoehenfriedberger Weg”, jaki spotykamy w pierwszych dwóch wydaniach oryginału (Marabut, Gdańsk 1995 i 1996, s. 139). Por. przyp. 19. 
pelach (s. 27, 117) zastępuje naturalizującym epitetem церковные хоры (chóry cerkiewne / chóry kościelne; s. 30, 135; śpiew chóralny odgrywa ogromną rolę w liturgii prawosławnej, gdzie nie używa się instrumentów).

Jednak rozstawienie akcentów w przekładzie przesuwa się przede wszystkim za sprawą paratekstu. Starosielska opatruje przypisami kilkanaście elementów kulturowych i zwrotów związanych $\mathrm{z}$ katolicyzmem, tym samym ogniskując na nich uwagę czytelnika. Trudno zaprzeczyć, że rosyjski czytelnik może mieć problem z rozszyfrowaniem zapisanego łacinką skrótu INRI ${ }^{28}$, z pojęciem gromnicy i adwentu, nie zna też święta Bożego Ciała ani zakonu cystersów - toteż działania objaśniające podejmuje tłumaczka $\mathrm{w}$ interesie odbiorcy docelowego. Jednak w rezultacie zamiast znaczącego, choć delikatnie zasugerowanego braku, jaki obserwujemy $\mathrm{w}$ oryginale, $\mathrm{w}$ przekładzie pojawia się znaczący nadmiar: wyeksponowanie obrządku katolickiego. Notabene w przypisie poświęconym świętu Bożego Ciała (s. 197) nie zamieszczono informacji o jego wymowie teologicznej, polemicznej wobec protestantyzmu, który nie uznaje przeistoczenia. Natomiast jedyna opatrzona objaśnieniem aluzja do protestantyzmu to myśl Hanemanna, iż w kwestii spowiedzi „rację miał wittenberski doktor” (s. 170) - „он чувствовал, что виттенбергский доктор был прав...” (s. 198). Starosielska eksplikuje (s. 198), że chodzi tu o Marcina Lutra, ojca reformacji w Niemczech.

Szczególne miejsce wśród nawiązań kulturowych zajmują w powieści Chwina odniesienia do twórczości i losu Heinricha von Kleista, jako element kolejnej niemiecko-polskiej opozycji, opartej na postaciach dwóch artystów samobójców: Kleista i Witkacego.

Podjęcie wątku Kleista w przekładzie ma charakter tworzenia nowej refrakcji. Autor Księcia Homburgu nie jest bynajmniej postacią nieznaną w Rosji. Jego dramaty przełożył w początkach wieku XX Borys Pasternak ${ }^{29}$, Kleist ceniony jest też przez Rosjan jako nowelista ${ }^{\circ}{ }^{\circ}$. Szkice o symbolicznym samobójstwie niemieckiego romantyka napisali między innymi Pasternak oraz I.Н.Ц.I.

${ }^{28} \mathrm{~W}$ językach cerkiewnosłowiańskim i rosyjskim funkcjonuje skrót

${ }_{29}$ Przetłumaczył Rozbity dzban (w 1914 r.), Księcia Homburgu oraz mniej znane w Polsce dramaty Rodzina Schroffenstein i Rebert Guiskard (w latach 1918-1919).

3० Por. А. Карельский, О творчестве Генриха фон Клейста, w: Г. Фон Клейст, Избранное. Драмы, новелль, статьи, Художественная литература, Москва 1977, s. 14-18. 
emigracyjny pisarz rosyjski Władimir Weidle ${ }^{3}$. Jednak utworów Kleista dawno nie wznawiano, a materiały, które wykorzystał Chwin - fragmenty listów Kleista i Henrietty Vogel oraz wspomniana relacja oberżysty - o ile się orientuję, nie miały dotąd przekładu na język rosyjski. Fragmenty tych dwu tekstów - za pośrednictwem polskiej wersji ${ }^{32}$ - Starosielska włącza zatem do kultury docelowej.

Dodajmy, że kreowanie wyobrażonego w utworze literackim wizerunku miejsca dokonuje się także przy użyciu środków pozawerbalnych, i one również wpływają na recepcję czytelniczą. Dlatego badając asocjacyjny potencjał interesującego nas dwutekstu, warto wziąć pod uwagę także przesunięcia w sferze paratekstów o charakterze graficznym.

W znanych mi wydaniach polskich Hanemanna na okładkach umieszczono reprodukcje prac Caspara Davida Friedricha: $\mathrm{w}$ pierwodruku i kilku innych edycjach ${ }^{3}$ - Wschód księżyca nad morzem $^{34}$, w wydaniu Świata Książki ${ }^{35}$ - Okresy życia ludzkiego ${ }^{36}$. Choć obrazy te odznaczają się stosowną do nastroju powieści melancholijną tonacją i przedstawiają sylwetki ludzkie na tle morza, to żaden $\mathrm{z}$ nich nie wskazuje na Gdańsk, ani przez bezpośrednio przywoływaną ikonografię, ani też przez osobę autora, który z Gdańskiem związany nie był. Malarstwo Friedricha po prostu ewokuje kulturę niemiecką en gros, zaś konkretne dzieła - wnoszą kontekst nadmorski (malarz urodził się na Pomorzu Przednim, w Greifswaldzie). Motywację dla ich użycia stanowi fakt, że wśród „cytatów malarskich” włączonych do utworu Chwina najczęstsze są przywołania właśnie Friedricha. Wszakże litografia, która według powieści wisiała w mieszkaniu Hanemanna, była reprodukcją innego obrazu tego malarza, słynnego Krzyża w górach (s. 21, 172). Dlatego związek między rzeczywistością powieściową a paratekstami graficznymi polskich wydań jest związkiem fakultatywnym.

${ }^{\text {I }}$ Zob.: Б. Пастернак, Генрих Клейст, w: idem, Об искусстве. «Охранная грамота» и заметки о художественном творчестве, Москва 1990; idem, Г. фон Клейст. Об аскетике в культуре, w: ibidem; В. Вейдле, Ванзее. 1811 , w: idem, Вечерний день. Отклики и очерки на западные темы, Издательство имени Чехова, Нью Йорк 1959.

${ }^{22}$ Chwin korzysta z przekładu Wandy Markowskiej według wydania: H. von Kleist, Listy, thum. W. Markowska, Warszawa 1983.

33 Marabut, Gdańsk 1995; Marabut, Gdańsk 1996; Słowo/obraz - terytoria, Gdańsk 1997; Tytuł, Gdańsk [2008] (wydanie, na którym opieram się w niniejszym artykule; projekt okładki - T. Bogusławski).

34 Mondaufgang am Meer, 1822, Alte Nationalgalerie, Berlin.

35 Warszawa 1998.

${ }^{6}$ Die Lebensstufen (Strandbild, Strandszene in Wiek), ok. 1835, Museum der bildenden Künste, Lipsk. 
Podobnie jak w oryginale, tak i w przekładzie Starosielskiej malarstwo Friedricha pojawia się aż pięciokrotnie (s. 23, 142, 200, 249; s. 115 - aluzyjnie). Na okładce edycji przygotowanej przez wydawnictwo ACT-Люкс widnieje jednak reprodukcja fragmentu Sadu Ostatecznego Hansa Memlinga. Tryptyk ten nie jest wprawdzie kojarzony z Niemcami (Memling był malarzem niderlandzkim, choć pochodzenia niemieckiego), natomiast stanowi swego rodzaju emblemat Gdańska: zdobyty przez gdańskiego kapra, na kilka wieków zawisł w Bazylice Mariackiej, gdzie do dziś znajduje się jego kopia ${ }^{37}$. Losy obrazu wielekroć wędrującego po Europie jako łup mogą też być symbolem i wielokulturowości, i losów miasta. Co ciekawe, strona redakcyjna ani kolofon nie informują o źródle ilustracji. Zatem czytelnik rosyjski - jeśli nie zna tego dzieła - będzie mógł je zidentyfikować dopiero na podstawie informacji wewnątrztekstowej. Lektura dwu fragmentów powieści nawiązujących do centralnego obrazu tryptyku odsyła do wyobrażenia archanioła $\mathrm{z}$ włócznią i wagą, a ich wierny przekład czyni wspomnianą identyfikację prawdopodobną:

[...] choć na obrazie Memlinga, na którym archanioł Michał oddzielał ocalonych od przeznaczonych na zatracenie, paliły się już jasne obłoki. (s. 34)

[...] był zupełnie podobny do mężczyzny z włócznią i wielką wagą, który na obrazie Memlinga ważył sprawiedliwych i grzeszników przed strąceniem ich do piekielnej otchłani. (s. 77)

[...] хотя на картине Мемлинга, где архангел Михаил отделял прощеных от обреченных на гибель, уже горели светлые облака. (s. 38)

[...] он как две капли воды походил на того мужчину с копьем и огромными весами, который на картине Мемлинга взвешивал праведников и грешников перед тем, как столкнуть их в преисподнюю. (s. 88)

Dodajmy, że wykorzystanie jako wizytówki książki dzieła sztuki, które nie jest ani polskie, ani niemieckie, lecz „gdańskie”, a które ponadto przez pierwszą dekadę powojenną stanowiło eksponat Ermitażu, może zostać odczytane nawet jako wzięcie w nawias serii niemiecko-polskich opozycji budujących powieść.

37 Mimo że Frauenkirche wspominane jest wielokrotnie na kartach powieści, poświęcony tryptykowi przypis Starosielskiej (ros., s. 38) odnotowuje jedynie jego współczesną lokalizację - Muzeum Narodowe w Gdańsku. 
Byłaby to niewątpliwie refrakcja, ale być może refrakcja całkiem po myśli autora. Twórczość Chwina ma przecież charakter koncyliacyjny, za co była zresztą nagradzana (Gdańska Nagroda im. Ericha Brosta, 1997).

Podsumujmy. Pomimo staranności przekładu Kseni Starosielskiej obserwujemy w nim pewną refrakcję imaginowanego obrazu dawnego Gdańska. Przesunięcia częściowo wynikają z ograniczeń narzucanych przez różnice systemowe między trzema wchodzącymi w interakcję językami, po części też wiążą się z odmiennym bagażem kognitywnym odbiorców pierwotnych i odbiorców docelowych. Niektóre przesunięcia są natomiast rezultatem celowych działań thumaczki, choćby dodanych paratekstów. Czytelnik rosyjski otrzymuje jednak przekonujący i bogaty w odniesienia kulturowe obraz Freie Stadt Danzig.

„Dzieło zyskuje czytelników i wywiera wpływ głównie dzięki [...] refrakcjom”, pisze Lefevere ${ }^{3}$. Może ono również samo stać się ośrodkiem refrakcji: wspomniałam w tym kontekście o von Kleiście, jednak twórczość Chwina może również przyczynić się do wypełnienia luki w kulturze docelowej, jaką była - i jest przemilczana niemiecka przeszłość części Prus, zajętej po II wojnie światowej przez Związek Radziecki. Kaliningradzki autor Jurij Bujda w powieści Pruska narzeczona pisze o trudności pogodzenia się z historyczną pustką miejsca, w którym dorastał. Przeszłość wymazano: „[...] kilka książek podawało żałosną garść informacji”, zaś pytania: „A życie? Jakie to było życie?” - pozostawały bez odpowiedzi lub sprowadzane były do negatywnych stereotypów etnicznych 39 . Utwór Chwina, także w swojej rosyjskiej hipostazie, próbuje się z takimi pytaniami mierzyć. Dlatego Hanemann, polska powieść o polskim mieście z niemiecką przeszłością, poddany refrakcji w rosyjskim kontekście językowo-kulturowym, może - zgodnie z ujęciem Lefevere'a - stać się ośrodkiem, w którym nastąpi refrakcja innego tekstu $4^{\circ}$, mianowicie tekstu kultury, jakim jest pamięć o niemieckiej przeszłości terenów obecnie należących do Rosji.

$3^{8}$ A. Lefevere, Ogórki Matki Courage, s. 226.

39 J. Bujda, Pruska narzeczona, thum. M. Buchalik, Czytelnik, Warszawa 2002, s. 7-8 (Ю. Буйда, Прусская невеста, Новое литературное обозрение, Москва 1998).

$4^{\circ}$ A. Lefevere, Ogórki Matki Courage, s. 226. 


\section{MARTA KAŹMIERCZAK}

\section{On Germanness of Gdańsk in the Russian translation of Stefan Chwin's Hanemann}

The article discusses representation of a third culture in translation: it compares the image of Gdańsk as a city with strong German cultural presence, presented in Stefan Chwin's novel Hanemann, with the same image in Ksenia Starosielska's Russian translation of the novel.

The image of the old Danzig in Chwin's work consists of linguistic allusions and references to German literature: interpolations, German proper names, realities from early decades of the 20th century, and the figure of Heinrich von Kleist. Some elements of language and notions in the novel could seem more distant for a Russian reader than for a Polish one. The present author considers, thus, if and how reality and topography of the city have been presented to secondary receipients. The article focuses on the translator's strategy of approach to a third culture, reflected both in translator's choices in the main text, as well as the number and formulation of footnotes. Because images of places in text are also created by non-verbal means, the graphical paratexts are also interesting for the discussion. The transformations are discussed in terms of refraction, which leads to conclusions about the role of the analyzed translation in its target culture.

Keywords: translation, third culture, imagination, refraction, Gdańsk, German, Ksenia Starosielska.

Marta Kaźmierczak - rusycystka, anglistka, absolwentka UŁ, obecnie adiunkt w Instytucie Lingwistyki Stosowanej UW. Autorka rozpraw poświęconych zagadnieniom przekładu i recepcji (dotyczących m.in. Bolesława Leśmiana, Johna R.R. Tolkiena, Michaiła Lermontowa, Czesława Miłosza) oraz monografii Przekład w kręgu intertekstualności (2012).

e-mail:mkazmierczak@uw.edu.pl 